\title{
The Analysis of Value Added Tax (Vat) to Increasing Government Revenue in Ethiopia
}

http://doi.org/10.21272/fmir.3(2). 115-127.2019

S. N. Singh

Dr, Associate Professor of Economics and Law in the Department of Economics, Faculty of Business and Economics, Mettu University, Ethiopia

\begin{abstract}
The value added tax is a significant source for increasing the revenue of the Government in Ethiopia. It is a family of indirect tax paid on the value added to goods and services by enterprises at each stage of the production and distribution process. The main objective of the study is to analyze the contribution of VAT to increase the governments' revenue and makes comparative analysis with other types of taxes. In order to drive the main objective of study the secondary source of data is being under persuasion. Most of the data are secondary by nature and collected through internet sources, newspapers, published and unpublished reports of the Government of Ethiopia etc. Furthermore, the study has to use simple descriptive statistical methods like table, percentage, and chart to analyze the data.

The significance of the study of VAT is the most important for regional and federal government of Ethiopia in order to minimize the gap between revenue generated and expenses occurred thereon. There are only few researches have been carried out on the same subject in the past and this study shall pertain to update literature helping to future research in respect to same concern. The scope of the study is lying down on emphasizing to identify the role of VAT as one of the best means to in increasing the revenue of Ethiopian Government. The study pertains to analyze various types of taxes had been introduced during 2005 to 2010 according to Ethiopian Calendar (EC) by the Federal Democratic Republic of Ethiopia.
\end{abstract}

Keywords: Value Added Tax, Government revenue, Economic growth, Descriptive statistics and the Significance.

JEL Classification: G32.

(C) The Authors, 2019. This article is published with open access at Sumy State University.

Cite as: Singh, S. N. (2019). The Analysis of Value Added Tax (Vat) to Increasing Government Revenue in Ethiopia. Financial Markets, Institutions and Risks, 3(2), 115-127. http://doi.org/10.21272/fmir.3(2). 115-127.2019

\section{Acronyms}

CSA Central statistical Authority

EC Ethiopian Calendar

EFIRA Ethiopian Federal Inland Revenue Authority

ERCA Ethiopian Revenue and Custom Authority

FDRE Federal Democratic Republic of Ethiopia

GST Good and services Tax

GTP Growth and Transformation plan

MOFED Minister of Finance and Economic Development

OECD Organization of Economic cooperation and Development

VAT. Value Added Tax

\subsection{Introduction}

1.1 Background of the study. Most developing countries are currently dependent on external financial resources of fund to their development activities as a result their budgetary problems become more serious/complex and to avoid external burden the developing nations must have to strengthen their domestic financial 
Financial Markets, Institutions and Risks, Volume 3, Issue 2, 2019

ISSN (online) - 2521-1242 ISSN (print) - 2521-1250

resource like Value Addition Taxes in order to accelerate sustainable development (Jones and Rhoades, cited in Muluneh, 2016)

Out of many one of important source of revenue generation is taxation, which is a system of raising money internally to finance government expenditure. Moreover, a tax is a compulsory payment to the Government without expectation any direct returns or benefits to the tax payers. It is a compulsory contribution imposed by the public authority, irrespective of the exact amount of service render to the taxpayers in return to the amount of tax paid by them thus, a tax is not paid in exchange of any specific benefits. For example, a person who has accomplished his tax obligation and another one is not. However, both will be enjoyed the same benefits from the public goods and services, which is commonly available for everyone to use and the public goods are usually financed by tax revenue (Worku, 2009).

Tax can be classified as direct and indirect tax. Direct taxes refer to those taxes that are collected from the people or organizations on which they are apparently imposed. The economic effect of this tax necessarily falls at the point where it is legally levied. For instance, a tax on employment paid by employers will have a direct impact on the employee, not on the employer. In contrast, indirect taxes are collected from someone other than the person presumably responsible for paying the taxes. They are avoidable taxes. That means indirect taxes can be avoided if the customers (indirect tax payers) refused to purchase and use the taxable goods (Addis Zemen,2016).

Value Added Tax is one of the most important sources of internal funds for developing countries such as Ethiopia. It is a family of indirect tax paid on the value added to goods and services by enterprises at each stage of the production and distribution process. It arises whenever a taxable person makes a supply of goods or services in the course of business operations. Thus, in some countries, it is called Goods and Services Tax (GST). Mourice Laure, a French economist and director of the French tax authority, started VAT first in 1954. It was invented because very high sales taxes and tariffs encouraged cheating and smuggling (Worku, 2017).

Taxes are important sources of public revenue the existence of collective consumption of goods and services necessitate putting some of our income into government hands. Such public goods like roads, power, municipal services, and other public infrastructures have favorable results on many families, business enterprises, industries and the general public. Public goods are normally supplied by public agencies due to their natures of non-rivalry and non-excludability. The nature of consumption of public goods is such that consumption by one does not reduce consumption for others besides consumption of public goods by an agent does not exclude others from doing same. Such nature of public goods therefore makes them impossible for private suppliers to avail them at market prices like other commodities. Government interventions in the supply of public goods is therefore inevitable and can only be done if the public pays taxes for the production and supply of goods and services respectively (Michael keen,2015).

Ethiopia has introduced Value Added Tax (VAT) first time in the year 2003 as a replacement of sales tax and VAT is now has become the principal source of internal revenue generation for the Government of Ethiopia for instance, in the financial year 2014 to 2015, the federal VAT revenue (on domestic transactions) accounted for about 41 per cent of total federal revenues from domestic sources according to Ethiopian Federal inland Revenue Authority(EFIRE 2017).Furthermore, since its introduction the VAT has been more revenue productive than sales tax (Teferra 2016) in order to sustain VATs revenue role in the governments finance to ensure the revenue generated by this tax system is raise as more efficiently as possible. However, in Ethiopia the revenues raised by VAT are usually garnered at the expense of erosion in its salient features. This may be caused by factors including poor VAT administration, i.e., the incapacity of tax authorities to implement the attributes of the taxes in real practice as a result the good tax administration is essentially required for fully implementation of the design features of VAT and achieving governments policy perspective/objectives at a large (Muluneh ,2017).

1.2 Statement of the Problem. Literally, France was the first country to introduce value-added tax (VAT) just before five decades ago to generate additional revenue for the government. Now the dimension of VAT has raises about $20 \%$ of the world's tax revenue, and affects about 4 billion people across. VAT is widely adopted in sub-Saharan Africa and elsewhere, it has been the centerpiece of tax reform in many developing countries including Ethiopia. The VAT has been recognized as a significant contributor for development of economy of any respective country. The causes and consequences of rising VAT have virtually not received any attention, either theoretical or empirical (Gebrie, 2016). 
The analysis of VAT in existing situation is significant to increase the governments revenue although many problems such as multi policy of taxes leads inconvenience to both the VAT authority and tax payer, the administrative cost used for collection of such taxes is generally huge because these are collected from a large number of people. The VAT plays a pivotal role in increasing the revenue of the government reflecting static welfare loss from four sources which are, compliance costs that are borne by taxpayers, administrative cost incurred by governments, the excess burden of the tax, and political costs associated with implementing and affecting tax law (Addis Zemen, 2017). Thus, the questions are expected what are the causes for significantly contribution of VAT in the economy? In addition to know what is the share of VAT in overall activities of the economy? The paper has to explore pros and cons of VAT on the revenue of Federal Government of Ethiopia and its contrast effects on social welfare of the economy.

1.3. Research questions. The followings are the major research questions that are supposed to be answered in this study.

- What is the contribution of VAT in increasing the revenue of federal government of Ethiopia?

- What is the nature of Value Added Tax (VAT) and how does it differ from other kind of tax?

- What is the effect of VAT on the other indirect tax revenue of the governments as compared to sales tax?

\subsection{Objective of the Study}

1.4.1. General objective of the study. The general objective of the study is to analysis of Value Added Tax to increase the revenue of Government one side and accessing other comparative advantageous and disadvantageous along with other types of taxes another side.

1.4.2. Specific objectives of study. The specific objectives are as follow:

- To assess the contribution of VAT on economic growth in Ethiopia;

- To compare the proportion of revenue rose from VAT with chorally to other taxes;

- To assess the effect of VAT on the total indirect tax revenue of the governments as compared to sales tax.

1.5. significance of the study. In context to Ethiopian economy the VAT has been observed as one of the most important tax systems to increase the governments' revenue as well as boost up economic growth of the country according to Growth and Transformation Plan (GTP). The purposes of studying this research are more significant because it discusses the major problems of VAT, and its contribution to the government revenue. Studied on the value added tax as a source of Government revenue are few. Hence this paper will produce an updated literature which will be used as an important starting point for future researchers in Ethiopia.

1.6. Scope of the Study. Many taxes have been introduced by FDRE in order to increasing governments revenue for accelerating economic growth in the economy, this paper will give more emphasis on identifying the role of Value Added Tax in increasing the governments revenue in Ethiopia. The study covers a fiscal period from 2005 to 2010 E.C chronological period of time and covering all other types of tax anticipation introduced by FDRE applicable in Ethiopia.

1.7 Limitation of the study. In spite of important contributions of VAT, this taxation system has not been utilized at utmost level corresponding to various limitations. The study pertains mainly two types of limitations i.e. lack of reliable data on Value Added Tax in Ethiopia and non-availability of literature on the same concern except few literatures in context to Ethiopia. The present study will fulfill the gape of shortcoming and also recommend some important policy enhancement in order to improve and strength the VAT in the country.

\section{0.. Literature Review}

2.1. Theoretical literature. A tax often takes its name from the base on which it is computed. For example, personal income taxes are levied against a base of personal income, and retail sales taxes are a proportion of final sales. Value added taxes are no exception. They are being levied on the value of newly produced goods and services (Ruebling, 2015). 
Financial Markets, Institutions and Risks, Volume 3, Issue 2, 2019

ISSN (online) - 2521-1242 ISSN (print) - 2521-1250

Value Added Tax (VAT) is a general consumption tax assessed on the value added to goods and services. It is a general tax that applies, in principle, to all commercial activities involving the production and distribution of goods and the provision of services. It is a consumption tax because it is borne ultimately by the final consumer. It is not a charge on companies. It is charged as a percentage of prices, which means that the actual tax burden is visible at each stage in the production and distribution chain. It is collected fractionally, via a system of deductions whereby taxable persons (i.e., VAT-registered businesses) can deduct from their VAT liability the amount of tax they have paid to other taxable persons on purchases for their business activities. This mechanism ensures that the tax is neutral regardless of how many transactions are involved (Herouy, 2017)

VAT has spread throughout the world since its introduction in 1955. France is credited first to implement VAT. It did so in 1955. It spreads through Europe, South America and parts of Africa in the 1960s and 1970s before taking a hold in other regions. For example, the tax spreads throughout the South East Asia/Pacific region from 1984 (Indonesia) to 1999 (Australia). Today, over 128 countries have this tax. All members of the Organization for Economic cooperation and Development (OECD) and all leading economies in the world have a VAT, apart from the US (Herouy, 2015).

VAT is a tax not on the total value of the good being sold, but only on the value of the value added to it by the last seller. The seller, therefore, is liable to pay a tax not on its gross value, but net value that is the gross value minus the value of inputs. The difference between VAT and a sales tax liability under vat is split up into stages. Theoretically the tax liability in the case of vat and in the case of sales tax at retail level should turn out to be the same this is because the total retail price is nothing but the value added to the raw materials at different stages of production and trade. In the case of vat, the same total of created value is taxed in stages. The usual practice is to estimate the tax liability of the last seller on the bases of gross value of the produce and give him credit for the taxes paid by the earlier sellers (Bhatia, 2016)

Value Added Tax belongs to the family of sales taxes therefore; it would be helpful distinguish between different forms of sales taxes and note the place of VAT in them. A general sales tax is a tax on sales transaction but it is applied at only one stage of business activity right from the manufacturer to the retailer. Usually its collected either at the wholesale level or a retailer level. The traders are allotted sales tax numbers and a trader possessing such a number can purchase the goods without paying the sales tax the similarity sales the goods to the next buyer net if sales is the next buyer also happens to possess a sales tax is the turn over tax is imposed only at one point of sale, a turn over tax is imposed at each sales transaction (Bhatia, 2016).

Since January 1, 2003, Ethiopia has introduced value added tax which is commonly referred as a consumption tax. The government has introduced this new tax and turn over tax to replace the sales tax. VAT eliminates the cascading effects on the sales tax, improves allocations and raise additional tax revenue for financing government expenditure. The impact of VAT clearly felt in the following year. In 2011 the revenue collected from VAT was birr 4809.15 million. This amount increased to birr13677.94 million in 2015. During this period the VAT revenue grew on average by $30.43 \%$ per year. In terms of consumption of VAT revenues, it shows a steady decline in the share of VAT on import from $62.16 \%$ in 2011 to about $46.03 \%$ in 2015 in Ethiopia. On the other hand, the share of VAT on domestic has been exhibited a steady increase from $37.84 \%$ in 2005 to $53.97 \%$ in 2015 in Ethiopia. Thus, since 2010 the ratio of VAT on domestic to VAT on import become greater than their ratio index value, which shows normal relationship between VAT on domestic and VAT on import are being on the right trends (Ethiopian Revenues And Customs Authority (ERCA), 2017).

\subsubsection{How Does the VAT Work?}

Value added tax is one of the most important sources of internal funds for developing countries such as Ethiopia. It is a family of indirect tax paid on the value added to goods and services by enterprises at each stage of the production and distribution process. It arises whenever a taxable person makes a supply of goods or services in the course of business operations (Worku, 2017). The ingredients of VAT as followsk:

- The tax is charged on certain transactions such as the sale of goods, the provision of services, and other types of supplies.

- It is charged at each stage of the production and distribution chain by businesses and other persons carrying on a continuous or taxable activity. 
- Such businesses do not incur the cost of the tax - they simply ensure that it is charged when they supply a commodity (collecting the tax on behalf of the Revenue) and claiming a credit from the Revenue for tax paid on their business inputs.

- Specified supplies are charged at the rate of $0 \%$ or are exempt from the tax. While Zero rated businesses can claim a credit for VAT paid on inputs, exempt businesses cannot

Registered for VAT.

Therefore, the tax is borne by VAT exempt institutions and unregistered end-consumers. Both parties pay the tax when acquiring commodities but are unable to claim a compensating VAT credit. These then are the characteristics of Value Added Tax regimes. Minor variations occasionally apply. In Canada and Australia, for example, exempt financial entities can claim a partial VAT credit on certain expenses (Herouy, 2015).

It has been mentioned in the above paragraph that the VAT is borne by VAT exempt institutions and unregistered end-consumers. The government of Ethiopian has used the concept of VAT exemption to subsidize the lower class of the society. As the cost of VAT is born mainly by non business end consumers, the lower class of the society or the poor ones cannot withstand with such challenge. The government has taken a measurement to overcome this challenge from the poor society of Ethiopia. VAT exemption has both advantage and disadvantage, especially, for those exempt institutions. That means they are unable to get VAT credit benefit, which is a deduction of VAT paid on inputs during production process. However, they are free from VAT on outputs.

2.1.2 How Does VAT Differ from Income Tax? VAT is borne by exempt institutions and unregistered endconsumers. Clearly, the latter consume more so VAT primarily taxes the non-business end consumer. In comparison, income tax applies across all spectrums of the community. Income tax is levied from income of the taxpayer, which is amounts coming in. VAT taxes spending i.e. amounts going out. Economic theory, therefore, classifies income tax as a "direct tax" and VAT as an "indirect tax" or a "consumption tax" (Herouy, 2016).

A VAT is often considered to be essentially a retail sales tax. However, a VAT differs from a retail sales tax in that it is collected at each stage of the production and distribution process, not solely at the stage where a product is sold to the consumer (Herouy, 2016).

2.2. Empirical Literature. The literature on the VAT is surprisingly sparse, given that it has now become a core part of the most countries' tax systems. while there is of course a large literature on the optimal design of taxes on final consumption, few contributions concern themselves with the crediting and refund mechanisms (and their potential imperfections) that make the critical difference between a VAT and, for example, a retail sales tax and which are therefore the distinctive source of any efficiency gain or loss associated with the VAT (Ebrill, 2016).

The literature establishing conditions under which uniform commodity taxation is optimal, for instance, just as applicable to any other form of consumption tax as it is to the VAT.Empirical work on the VAT is also scant. A few papers have sought to model the revenue raised by, and compliance with, the VAT, often with a view to estimating a revenue maximizing rate. Desai and Hines (2014) consider the impact of the VAT on international trade. Finding that particularly for other than high income countries both openness and export performance are negatively related to both the presence of the VAT and the extent of revenue reliance upon it. However, modeling the take up of the VAT. Only two studies i.e., the impact of the VAT on the efficiency of, and (a closely related aspect, as we shall see) the revenue rose by the full tax system. Nellor (2015), proceeding essentially by case study, provided an early assessment of the revenue impact of a few VAT adoptions. Closest to the present analysis, however, is Ebrill and others (2016), who address similar questions but do so using only a single cross-section of data, and as also do Desai and Hines (2014) and the other papers cited above taking the presence or absence of a VAT as exogenous. These restrictions mean that these previous results are subject to potentially serious biases.

Considering the significance of tax administration, many studies have been conducted in some developing and transitional countries with respect to the main VAT administration tasks. These studies include Jantscher (2014), Edmiston and Bird (2016), Bird and Gendron (2016), Grandcolas (2015) and Bird (2014) all papers assessed how VAT administrators in developing and transitional countries perform their duties and how the 
Financial Markets, Institutions and Risks, Volume 3, Issue 2, 2019

ISSN (online) - 2521-1242 ISSN (print) - 2521-1250

effective taxpayer requirements differ from the legislation. More specifically, the analyses focused on practices of different developing countries with respect to taxpayer identification, invoicing, filing and payment process, control With regard to the recently introduced Value Added Tax (VAT), arguments have been exchanged between the government and business community. These centered around the fear, that VAT is escalating the prices and services and weaken the purchasing power of the people, which is already low in Ethiopia. As a result, the VAT discourages investor to invest money for producing goods and services for local consumption and thus perpetuate poverty. The most serious threat to fair competition in a tax system with VAT is the flagrant contraband trade, especially through the hardly controllable Somali border (ERCA, 2017). In Ethiopia from December 2004 EC up to December 2005 EC the VAT raises about 1 billion birrs. This figure increases the government revenue by more than 10 percentages. If the system is implementing properly, the contribution to the government revenue would increase at alarming rate (Alliance Professional Consultancy, 2016)

Under this part the paper tried to see and summarized empirical and reaearch studies conducted in different countries related to the study. The contribution of value added tax (VAT) total revenue generation of Government in Nigeria empirical study was published September 2016 by Muhibat Abdul Azeez and Top Lawal. the objective of the study was to examine the contribution of Value added tax (VAT) to revenue generation and Government revenue in Nigeria since 2015. The study used Hypotheses in order to see the VAT revenue influences the revenue generation and the growth of the Nigerian economy. They collected and used secondary data of 18 years of VAT revenue and government revenue data from the publication of the central bank of Nigeria (CBN) and Federal Inland Revenue Service (FIRS). In Nigeria VAT reduced the dependency of the government on oil revenue. Nigerian federal in land revenue service (FIRS) is administered value added tax (VAT) and VAT is distributed among the three-tiers of the government in a particular ratio but the jurisdiction of VAT lies with the federal Government of Nigeria. According to IMF 2016 countries following the VAT system did have higher general government revenue and VAT contributes $20 \%$ of the total revenue. Thestudy used regression analysis method and found that a positive and significant correlation exist between VAT revenue and the growth of the Government using GDP as measurement because revenue is the major components of VAT (Abdul Aziz; 2016)

The role of value added tax on Government revenue of Ethiopia was written by Dasalegn Mosissa Jalata, March 2016. The objective of the research was to asses Value Added Tax (VAT) on growth Government revenue of Ethiopia from 2006 to 2015 based on theoretical and empirical evidences. The study used secondary data whh is collected on economics variables (Value Added Tax (VAT), Total Tax Revenue, Non- Tax Revenue and Foreign Revenue from Ethiopia Revenue and Custom Authority (ERCA), Ministry of Finance and Economic Development (MOFED), Ethiopian and Economic Association. In addition, the study also collected data from various documents, annual reports, financial statement and other published and unpublished statistical data for Ten (10) years. Time series information was used for statistical computation the relationship among variables. The study used descriptive statistics and multiple regression statistical methods of both SPSS statistical were employed. In addition, descriptive analysis techniques such as percentages and ratios methods of data analysis were used to see the relation among the above variables. By using descriptive analyses, the study concludes that: government revenue increased since 2003 because of Value Added Tax (VAT)adoption, the average ratio VAT revenue to the government revenue since 2003 to 2012 was $22.27 \%$, for the period between 2003 to 2012 the average ratio of VAT growth was $66.27 \%$ and there was huge fluctuation of growth rate of VAT as well, the average total government revenue for the study period was $22.82 \%$ and this indicate that there was Economic growth for the under study period, for year 2003 to 2012 the average ratio VAT to total tax revenue was $26.75 \%$, even though the contribution of VAT to the total tax revenue reduced VAT revenue had still economic contribution, on the other hand the average growth rate of total tax revenue was $27.44 \%$ this indicate that there was growth of tax revenue and Government revenue for the study period, during the reviewed period the average ratio of VAT revenue to Government revenue was $2.95 \%$ and this indicate that VAT has contribution for the revenue of the country. During the sales tax period the average growthof Government revenue was $2.53 \%$ and this was very low when we compare the average growth rates of government revenue with VAT, $21.9 \%$ and this clearly indicate that VAT had great contribution to the country economy growth and finally the VAT system in Ethiopia have only single or one standard rate and makes the taxing system to be regressive and this force the poor to pay the amount with rich and this have negative general impact on the economy growth of countries (Desalegh mosisa;2017) 


\subsection{Methodology of The Study}

3.1. Description of the study area. The study area is focused on Ethiopian. Ethiopia is located in the horn of Africa from $3 \mathrm{~N} 0-15 \mathrm{~N} 0$ and 48E and bordered on the north northeast by Eritrea on the east by Djibouti and Somalia on the south by Kenya on the North West by Sudan and on the southwest by South Sudan. The total area of country is 1,127, 177-kilometer square, the climate of Ethiopia in the tropical zone mining between the equatorial and the tropical of cancer. According to the elevation it has three different climate zone, kola, and wainadega and degas similar to tropical zone, sub-tropical zone and cool zone respectively.

Ethiopia has total population of 99.87 million of whom 49.34 million are men and 50.53 million are women. The majority of the inhabitants practiced Ethiopian Orthodox Christianity, with $43.55 \%$ of the population, while $33.9 \%$ of their populations were Muslim and $18.6 \%$ are protestant, $0.10 \%$ where Catholic, and $2.7 \%$ are traditional. Ethiopia consist many nations, nationalities and people like Oromo (34.4\%), Amhara (27\%), Tigre (6.1\%), Gambella (4\%), Garage (2.5\%), Sidama (4\%), Walayta (2.3\%), Affair (1.7\%), Hadya (1.7\%) ,Gamogofa (1.5\%) and other (5\%) within their culture, Languages and religions,(Internet source).

3.2. Data Source and Type. The data is macro by nature and focus the review of VAT in Ethiopia. The data use for this study was obtained from secondary sources data. The data would be collected from Internet sources, newspaper, published and unpublished reported of Government revenue. The data are both quantitative and qualitative types covered for the fiscal period from 2005 to 2010 EC. The amount of taxes collected from different e tax, business income tax, and other indirect taxes was collected from of the office's annual reports. Moreover, qualitative data are obtained from different reports and letters such as National Bank of Ethiopia Bulletin, Central Statistical Authority, and etc.

3.3. Method of data collection. The Ethiopian government has introduced VAT as one source of internal funds since 2003. It is that the study would yield considerable reliable information if it included all data of VAT before and after the introduction of VAT. Many constraints like time and cost limit threat the selection data particularly from 2005 to 2010 EC. The proportion of VAT collection to total tax, income tax and sales tax other than VAT would be analyzed using these data.

3.4 Method of Data Analysis. The method of data analysis was employed by using descriptive statistics. These includes percentage, ratio, fraction, table, graph and chart etc. and these help to comparation of VAT in the country during the projected period of time e.t, (2005 to 2010EC) as well as the impact of VAT on the government revenue.

\subsection{Discussion and Finding}

4.1 Description of the Data.The data obtained from internet source, newspaper, published and unpublished Government revenue there are two broad types of taxes, that are direct and indirect taxes. Under direct tax, we have personal income tax, business income tax, withholding tax on import, and others. Indirect taxes include value added tax, excise tax, turnover tax, stamp duty and custom duty (tariff). From all types of revenue sources, the government collect taxes several million of birr. The share of in direct tax is increasing throughout the study year namely 2005-2010, forexample in the year 2009 the share of indirect tax was $76.764 \%$ which indicates the important role of indirect taxes in total revenue. For each year under the study, the indirect taxes contribute more than $70 \%$ to the total government revenue.

This chapter of the paper presents the data gathered from primary and secondary sources on VAT collection and the effect of VAT exemption of imported food products by the Federal Government of Ethiopia during the last six years. Thus, this part of the paper is designed to address the extent to which VAT affected total tax revenue of the Federal Government.

\section{4 .2 Total Tax Collection by Federal Government of Ethiopia from Year 2005-2010 E.C.}

Following the liberalization of the economy, the Federal government of Ethiopia has taken taxation as the main source of government revenue. As it is shown in the table below, total tax collected during the projected years has increased from year to year. Indirect taxes have taken the lion share of the total tax collected through the considered period.

Table 4.1. Collection of tax Revenue, total tax growth Rate and tax Proportions (in millions of Birr)

\begin{tabular}{|l|l|l|l|l|l|l|}
\hline Year & 2005 & 2006 & 2007 & 2008 & 2009 & 2010 \\
\hline Direct Taxes & 307.32 & 398.07 & 480.98 & 556.17 & 794.17 & 1017.37 \\
\hline Personal Income Tax & \multicolumn{5}{|l|}{} \\
\hline
\end{tabular}




\begin{tabular}{|c|c|c|c|c|c|c|}
\hline Business Income Tax & 957.84 & 1031.62 & 1245.92 & 1658.25 & 2509.43 & 3661.76 \\
\hline Withholding Tax on Import & 184.58 & 191.78 & 240.80 & 294.55 & 344.83 & 530.14 \\
\hline Other Tax & 78.62 & 59.80 & 85.76 & 136.92 & 132.95 & 186.99 \\
\hline Total Direct Tax & 1528.36 & 1681.27 & 2053.46 & 2645.89 & 3781.38 & 5396.26 \\
\hline \multicolumn{7}{|l|}{ Indirect Tax } \\
\hline VAT & 3248.17 & 4032.03 & 4809.15 & 5931.48 & 7312.89 & 8988.18 \\
\hline Excise Tax & 907.04 & 1218.81 & 1221.12 & 1461.34 & 1862.88 & 2470.64 \\
\hline Turn Over Tax & 132.60 & 82.42 & 51.95 & 57.86 & 36.88 & 19.99 \\
\hline Custom Dies & 2185.48 & 2503.2 & 2953.81 & 3301.42 & 3891.82 & 3944.09 \\
\hline Sur Tax & 9.60 & 0.001 & 0.01 & 492.65 & 2210.20 & 2282.91 \\
\hline Stamp Duties & 53.11 & 75.18 & 84.22 & 104.08 & 109.47 & 121.62 \\
\hline Total Indirect Tax & 6516.00 & 7911.64 & 9120.25 & 11348.80 & 15424.10 & 17827.40 \\
\hline Total Tax Revenue & 8044.36 & 959291 & 11173.70 & 13994.70 & 19205.50 & 23223.70 \\
\hline Growth Rate to Total Tax & - & 0.1926 & 0.1648 & 0.2525 & 0.3723 & 0.2092 \\
\hline \multicolumn{7}{|l|}{ Ratio to Total Tax } \\
\hline Direct Tax & 0.18991 & 0.175262 & 0.183776 & 0.189263 & 0.19689 & 0.23236 \\
\hline Indirect Tax & 0.81009 & 0.822738 & 0.816224 & 0.810937 & 0.80311 & 0.76764 \\
\hline
\end{tabular}

Source: Ethiopian Revenue and Custom Authority 2010 E.C.

Other taxes $=$ Taxes from Housing Rent, Dividend income and Interest income.

The above table showed the structure and trends of tax revenue collected by the Federal government of Ethiopia during the last six years. Hear, it is clear that total tax revenue is the sum of direct taxes and indirect taxes. Compared to indirect taxes, total direct tax contributed very small amount to the total tax revenue. It was only $20 \%$ on average i.e.

$$
((0.1899+0.1753+0.1838+0.1891+0.1969+0.2324+0.1946) / 6)
$$

In contrast, indirect taxes contributed the largest amount to total tax revenue. Its share to total tax is around $80 \%$ on average i.e.

$$
((0.8100+0.8247+0.8162+0.8109+0.8031+0.7+0.8054) / 6)
$$

Thus, indirect tax was the main source of tax revenue for the Federal Government of Ethiopia. This share of revenue contribution trend for both direct and indirect taxes continued almost in all years of the data analysis. On the other hand, the data shows that total tax revenue has increased from year to year for the last six years. The increment reached its pick in 2009E.C. But the growth was less for the year 2007 compared to year 2006 E.C and for the year 2010compared to 2009E.C. This can be clearly shown using the following chart. (4.1).

The total tax revenue mainly comes from the indirect taxes especially from value added tax (VAT) as demonstrated by high proportion in total revenue. For the periods under study, VAT accounts for $38 \%-43 \%$ of the total tax revenue. In each year i.e. (2005 to 2010 ), the share of VAT is $40 \%, 42 \%, 43 \%, 42 \%, 38 \%$ and $38 \%$ percent for respective years between 2005 to 2010. Out of the indirect taxes, VAT still holds the lion share. It accounts nearly half of the revenue from indirect taxes.

The graph below shows that total tax revenue is increasing over the time given. Direct taxes contribute less to the total tax whereas the contribution of indirect tax in significant.

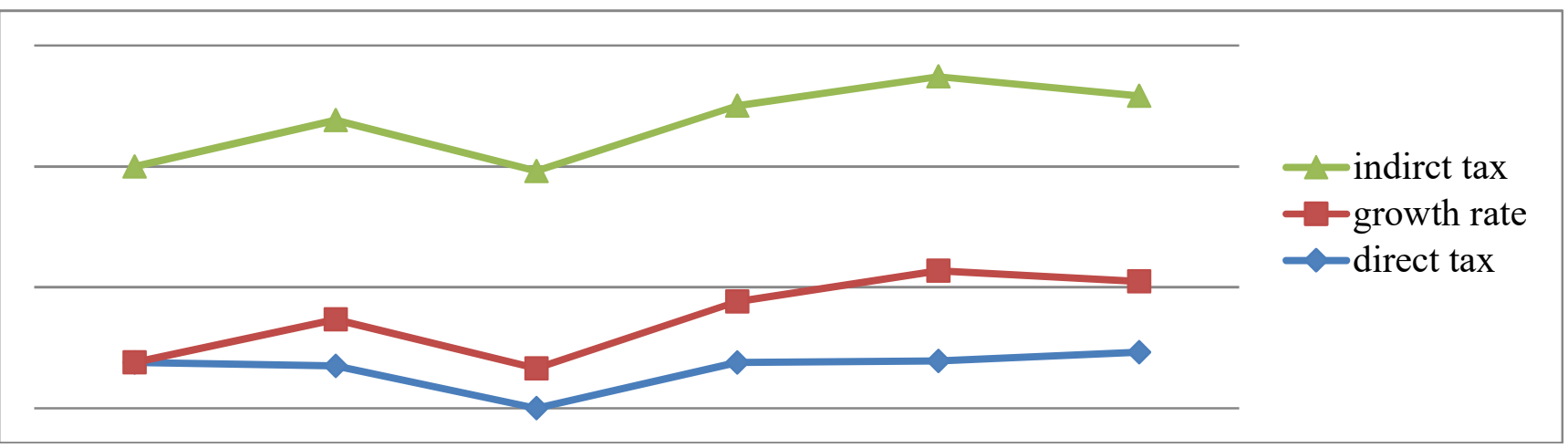

Figure 1. Total tax revenue

Source: by author. 


\subsection{Chart Trends of Proportion of Direct tax and indirect tax to total tax revenue and the growth rate of total tax revenue (2005-2010 EC)}

The above chart showed the trend of proportion of direct taxes and indirect taxes to total tax revenue as well as the growth rate of total tax revenue of the Federal government of Ethiopia for the last six years (20052010)It illustrated that the small contribution of direct tax to total tax revenue has continued with in the period for data is collected except the last year, 2010 E.C, which was a little bit above $20 \%$ of the total tax revenue. On the other hand, the chart clearly shows that the trend of proportion of indirect tax contribution to total tax revenue was above $80 \%$ from 2005 to 2010 E.C. But in 2010, it declined below $80 \%$ and reached around $77 \%$ of the total tax revenue, which was its minimum amount for the last six years of the analysis. The main reason for the declining of this proportion is the tax exemption that government undertook to reduce inflation.

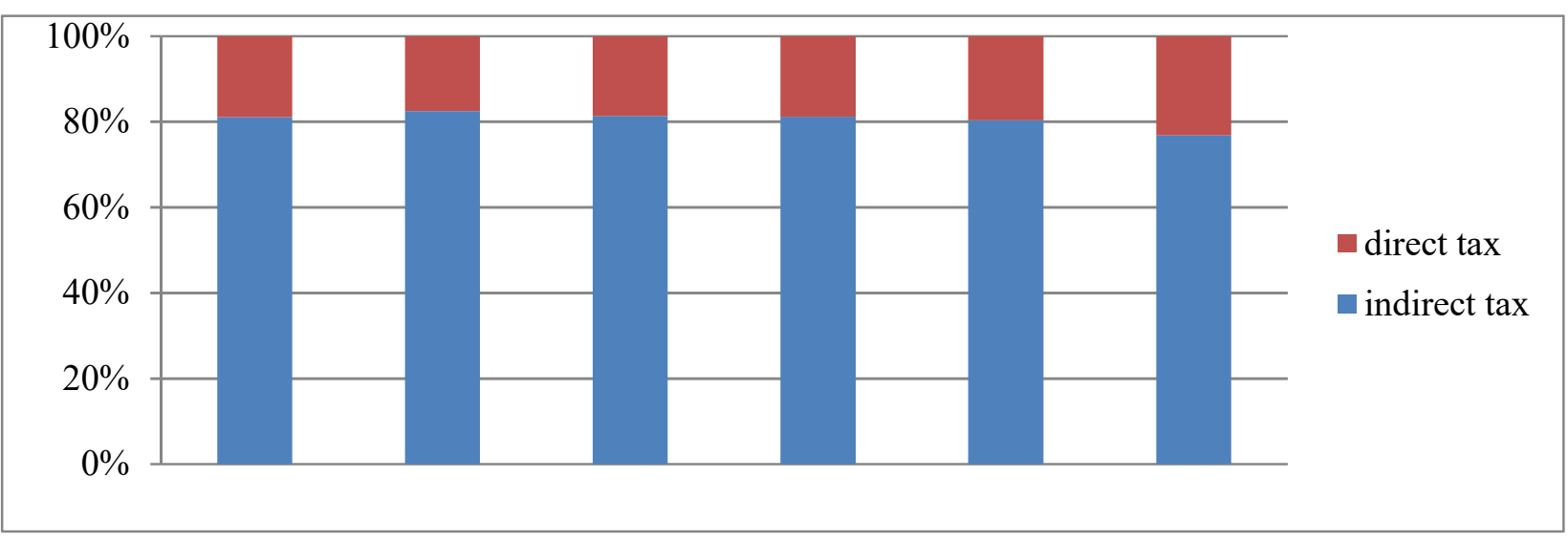

Figure 2. The tax exemption

Source: by author.

\section{Chart 4.2 proportion of dirct and indirect taxes( source own computation)}

Generally, according to the data on both the table as well as the chart above, indirect taxes are the main sources of tax revenue for the Federal Government of Ethiopia.

\subsection{Comparison of VAT Collection against Direct Taxes}

As it has been mentioned earlier, tax revenue collected from indirect taxes is very much greater than revenue collected from direct taxes. The proportion of tax revenues for direct and indirect taxes for the last six years was $2: 8$ on average. This effect has been reflected on the comparison of VAT against direct taxes also. The contribution of VAT collected to total tax revenue is greater than not only personal income tax or business income tax but also the total direct taxes as a whole. This situation was true for all six years of the study period. The following table summarizes the comparison of tax revenue contributed by VAT and those all taxes under direct tax category.

Table 4.2 Comparison of Tax Revenue Collected from VAT and All Direct Taxes by the Federal Government (in Millions Birr)

\begin{tabular}{|c|c|c|c|c|c|c|}
\hline Year & 2005 & 2006 & 2007 & 2008 & 2009 & 2010 \\
\hline Personal Income tax & 307.32 & 398.07 & 480.98 & 556.17 & 794.17 & 592.35 \\
\hline Business Income Tax & 957.84 & 1031.62 & 1245.92 & 1658.25 & 2509.43 & 3661.76 \\
\hline Other Direct Taxes & 263.62 & 251.56 & 431.47 & 477.78 & 717.13 & 411.36 \\
\hline Total direct Taxes & 1528.78 & 1681.27 & 2053.46 & 2645.89 & 5396.26 & 2847.84 \\
\hline VAT & 3248.17 & 4809.15 & 5931.48 & 7312.89 & 8988.18 & 5720.32 \\
\hline Other Indirect Tax & 1738.63 & 2189.34 & 2771.44 & 4329.85 & 3443 & 2789.8 \\
\hline Total Tax Revenue & 8047.36 & 9592.91 & 11173.7 & 19205.5 & 23223.7 & 14205.81 \\
\hline VAT/Total Tax & 0.4038 & 0.4203 & 0.4238 & 0.3808 & 0.387 & 0.4077 \\
\hline Direct Tax/Total Taxies Ratio & 0.19 & 0.1753 & 0.1838 & 0.189 & 0.2324 & 0.1946 \\
\hline
\end{tabular}

Source: Ethiopian Revenue and Custom Authority 2010.

The above table shows that VAT contributed around $41 \%$ on average to total tax revenue whereas total direct taxes contributed only $20 \%$ on average. That means the contribution of VAT to total tax exceeded the contribution of total direct tax revenue by a double amount. The trend of tax contribution of these taxes can be illustrated using the following chart: 


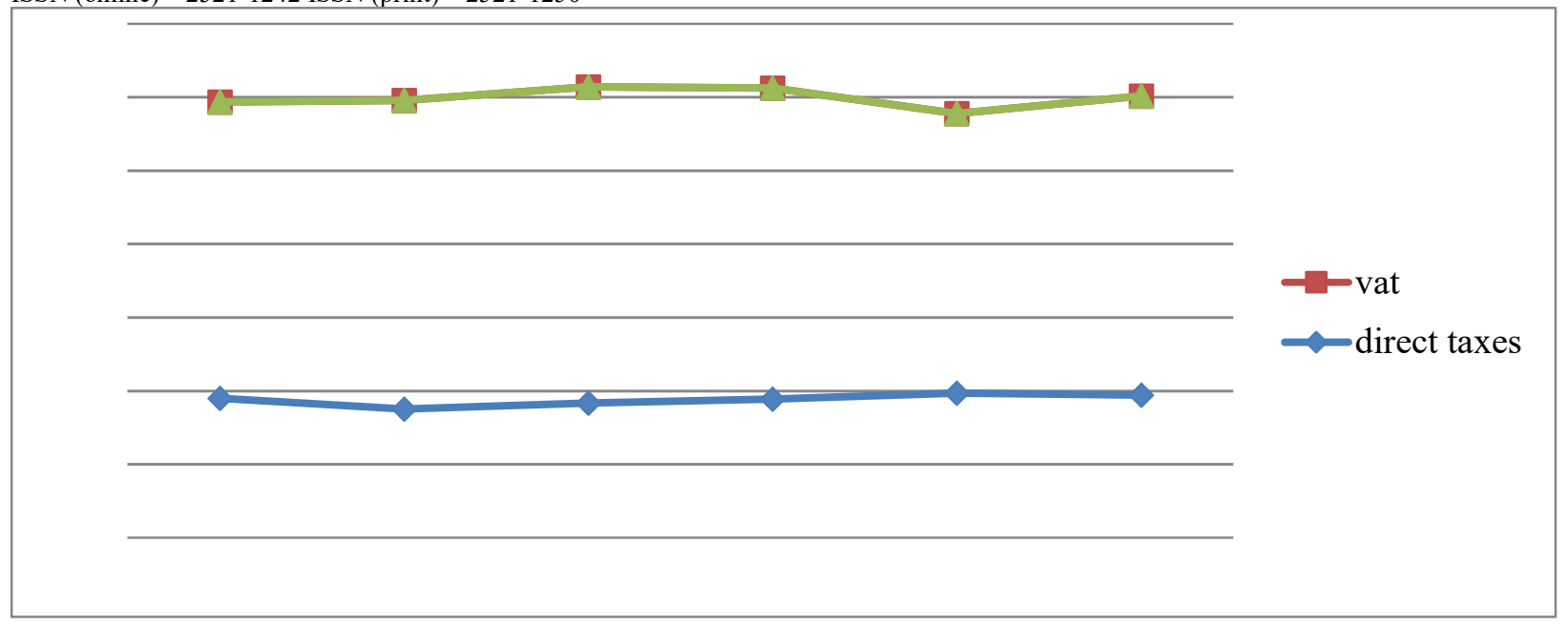

Figure 3. The trend of tax contribution

Source: by author.

\section{Chart 4.3 Trends of VAT and Total Direct Taxes Contribution to Total Tax Revenue}

From the above chart one can understand that revenue contribution ratio of VAT has experienced an increasing trend for the first three years of the data analysis (2005-2007). But this trend did not continue on the same fashion after the year $2007 \mathrm{EC}$. It declined below $40 \%$ tax contribution to total tax after this year. This effect reached its minimum ratio of $38.1 \%$ in $2009 \mathrm{EC}$. On the other hand, total direct tax to total tax ratio has increased almost in all years of the study period except $2006 \mathrm{EC}$, which showed a $2 \%$ decline. But it increased by $4 \%$ in 2008 E.C, which is a relatively large increment.

Generally, the chart as well as the table illustrated above summarized that the contribution of VAT to total tax is very large relative to total direct taxes. Thus, it can be concluded that compared to all direct taxes, VAT was the main force of tax revenue than all direct taxes for the last six years (2005-2010).

\subsection{Distribution of Tax Revenue under Indirect Tax Category}

Under indirect tax category of Ethiopia Government, the most frequently used tax types are value Added Tax (VAT), Custom Duties, Excise tax and Turnover Tax (TOT). Surtax and stamp duties are other sources of tax revenue which contribute the least amount of tax revenue collected from indirect tax category. The distribution of each tax under indirect tax category can be summarized using the table below:

Table 4.3. Distribution of Indirect Taxes from 2005-2010 EC, in Millions of Birr

\begin{tabular}{|l|l|l|l|l|l|l|l|}
\hline Year & $\mathbf{2 0 0 5}$ & $\mathbf{2 0 0 6}$ & $\mathbf{2 0 0 7}$ & $\mathbf{2 0 0 8}$ & $\mathbf{2 0 0 9}$ & $\mathbf{2 0 1 0}$ & Average \\
\hline Duty-Tax & 2165.48 & 2503.2 & 2953.81 & 3301.42 & 3891.82 & 3944.09 & 3126.63 \\
\hline VAT & 3248.17 & 4032.03 & 4809.15 & 5931.48 & 7312.89 & 8988.18 \\
\hline Excise Tax & 907.04 & 1218.81 & 1221.12 & 1461.34 & 1862.88 & 2770.64 & 1523.64 \\
\hline Turn Over Tax & 132.6 & 82.42 & 51.95 & 57.86 & 36.88 & 19.99 & 63.62 \\
\hline Other Tax & 62.71 & 75.18 & 84.22 & 596.73 & 2319.67 & 2404.53 & 923.84 \\
\hline Total Tax & 8044.36 & 9592.91 & 11173.71 & 13994.72 & 1920552 & 23223.69 & 14205.82 \\
\hline VAT/Total Tax & 0.4038 & 0.42 .03 & 0.4304 & 0.4238 & 0.3808 & 0.3807 & 0.4077 \\
\hline Duty-Tax/Total tax & 0.2692 & 0.2609 & 0.2644 & 0.2359 & 0.2026 & 0.1698 \\
\hline $\begin{array}{l}\text { Turn Over } \\
\text { Tax/Total Tax }\end{array}$ & 0.0165 & 0.0086 & 0.047 & 0.0041 & 0.0019 & 0.2201 \\
\hline
\end{tabular}

Source: Ethiopian Revenue and custom Authority 2010 E.C.

Based on the above table, one can easily understand that VAT, which contributed $41 \%$ on average to total tax revenue, was the largest source of tax revenue from indirect tax category. On the contrary, turnover tax, which contributed only $1 \%$ on average to total tax revenue, was the least source of indirect tax revenue for the Federal Government of Ethiopia. On the other hand, Duty Tax is the largest source indirect tax revenue next to VAT. It contributed around $23 \%$ on average to total tax revenue for the last six years of the data analysis. The following graph shows the trend of Indirect Tax Collection. 


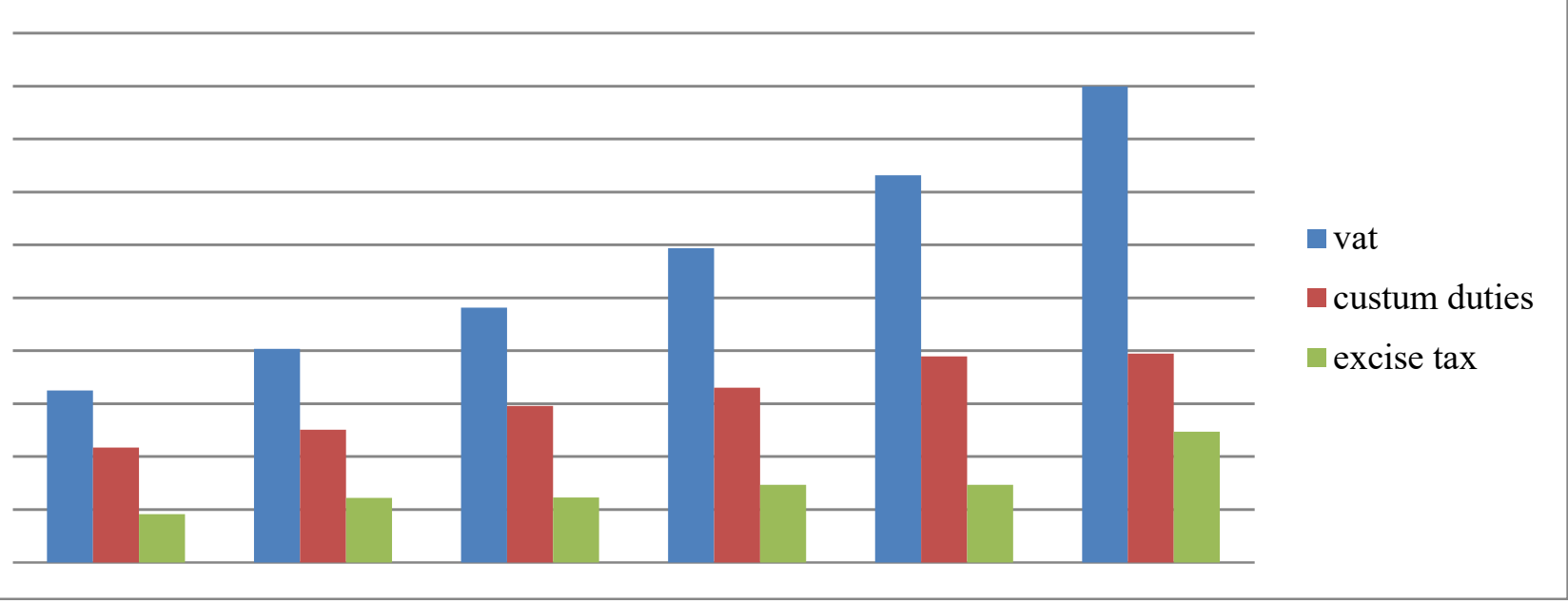

Figure 4. The trend of Indirect Tax Collection

Source: by author.

Chart 4.4 Indirect Tax Collection Trend from the Year 2005 to 2010 E.C

In general, VAT and duty tax, which constituted around $64 \%$ on average of total tax revenue, were the major sources of not only indirect taxes but also total tax revenue as a whole. Therefore, it can be concluded that indirect taxes are the main sources of tax revenue for the Federal Government of Ethiopia.

\subsection{Comparison of Proportions of VAT Collected Against Other Indirect Taxes}

It has been mentioned earlier that VAT was the largest source of indirect tax revenue in Ethiopia. In this section of the data analysis, comparison of VAT with other indirect taxes will be made wit in the period of study

In the previous discussion, it is shown that VAT and duty tax are the first and second largest source of total tax revenues for the Federal Government of Ethiopia within the last six years. According to the proportion data summarized in the table below, the contribution of VAT revenue to total tax revenue exceeded from that of Customs Duty Contribution by $18 \%(41 \%-23 \%)$.

Table 4.4 Comparison of Proportions of Vat Collected Against Other Indirect Taxes

\begin{tabular}{|c|c|c|c|c|c|c|c|}
\hline Year & 2005 & 2006 & 2007 & 2008 & 2009 & 2010 & Average \\
\hline \multicolumn{8}{|l|}{ Ratio to Total Tax } \\
\hline VAT & 0.4038 & 0.4203 & 0.4304 & 0.4238 & 0.3808 & 0.387 & 0.4078 \\
\hline Custom Duties & 0.2692 & 0.269 & 0.2644 & 0.2359 & 0.2026 & 0.1698 & 0.2338 \\
\hline Excise Tax & 0.1128 & 0.1271 & 0.1093 & 0.1044 & 0.097 & 0.1064 & $0-.1095$ \\
\hline Turn Over Tax & 0.0165 & 0.0086 & 0.0046 & 0.0041 & 0.0019 & 0.0009 & 0.0061 \\
\hline OtherIndirectTaxes & 0.0078 & 0.0078 & 0.0075 & 0.0426 & 0.1208 & 0.1035 & 0.0483 \\
\hline
\end{tabular}

Source: from Ethiopian Revenue and Custom Authority 2010 E.C.

Others indirect taxes such as surtax and stamp duties

On the other hand, TOT was the least contributor to total tax revenue from indirect taxes. It contributed only $1 \%$. Thus, VAT and TOT are the two extremes sources of tax revenue for government of Ethiopia. As it can be seen in the above two consecutive tables, TOT has decreased in amount and proportion from year to year ranging birr 132.6 million (1.65\%) in 2005 to birr 19.99 million $(0.09 \%)$ in $2010 \mathrm{EC}$. On the contrary, VAT has increased in amount for the last six years. It ranged from birr 3.25 billion (40.38\%) in 2005 to birr 8.99 billion (38.7\%) in 2010 E.C. The following chart compares the trend of each tax collection. 


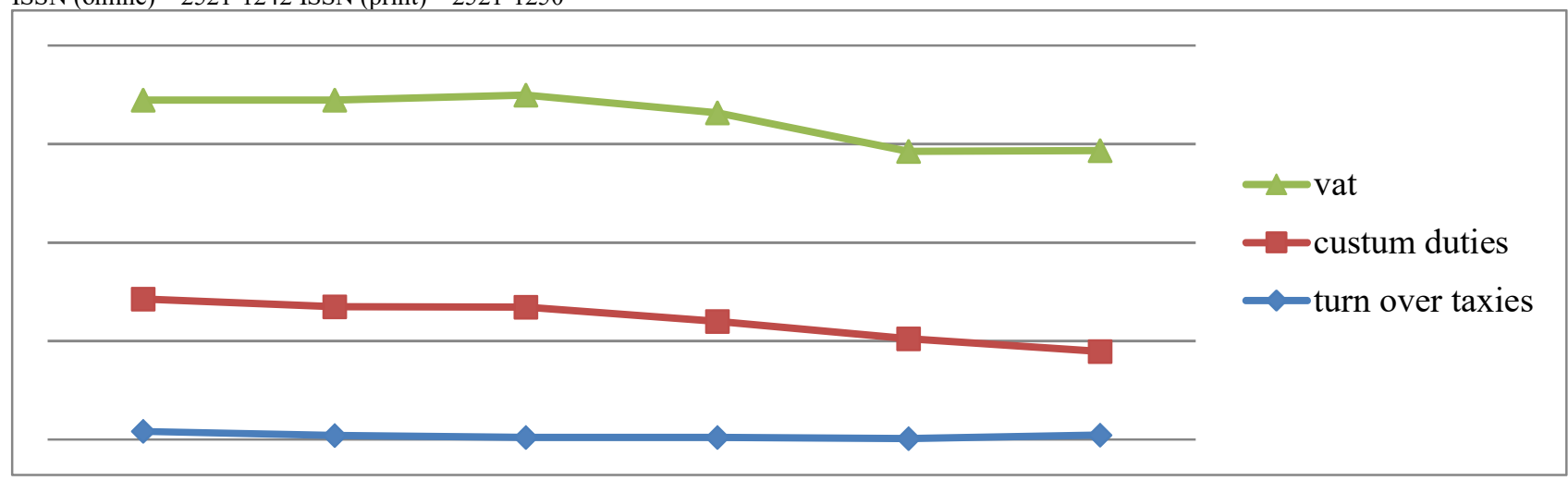

Figure 5. The trend of each Tax Collection

Source: by author.

\subsection{Chart Contributions of Indirect Taxes to Total Revenue by their Ratios from the Year 2007 to 2010 EC.}

Generally, we can put all indirect taxes based on the rank of tax revenue contribution for total tax as follow:

1. Value Added Tax (VAT)

2. Custom Duties

3. Excise Tax

4. Other Taxes

5. Turnover Tax (TOT)

Being the largest source of tax revenue, VAT will have a major influence on the government revenue. That means any structural change on VAT will have an impact on the tax revenue of the Ethiopian Government.

\subsection{Conclusion and Recommendations}

\subsection{Conclusion}

This paper has shown as the importance of VAT in increasing total government revenue. We conclude that value added tax contributes much to government revenue. Indirect taxes in general contribute more to total government revenue than direct taxes. This shows that importance of indirect taxes in government policies. Among the indirect taxes the value added tax (VAT) takes the highest proportion in the government revenue. This also strengthens the argument that VAT is not only the source of revenue but also an effective policy instrument. Because VAT is so important in government revenue generation due its wide applicability on every angle of the economy.

From the primary survey with officials in the Ethiopia revenue and custom Authority office, this is growing claim that VAT collection is problematic due to increasing tax evasion. Most business men under report their sales or do not register for VAT. This decreases the amount of VAT and other taxes to be collected. Given this problem the revenue from VAT is still increasing, except for the year 2000 following the VAT exemption that government undertake on certain food grain import such as wheat, rice, maize, Teff, sorghum etc. to reduce inflation. The use of VAT exemption by the government also shows the role of VAT in policy making.

VAT has a significant role in the revenue system of the Ethiopian government. To sustain VAT's revenue role in the government's finance, it is crucial to ensure that the revenue generated by this tax is raised as efficiently as possible. Nevertheless, in Ethiopia revenues generated by VAT are usually garnered at the expense of a compromise in its salient features. This is usually caused by factors including weaknesses in the administration, that is, the incapacity of the administration to put the attributes of VAT in practice.

\subsection{Recommendations}

Based on the above conclusion the following policy implications emanate from this study:

1. Use of indirect taxes help government to collect enough revenue than direct taxes 
2. Proper administration of Value added taxes are important for increasing government revenue. A good VAT administration is critical in fully implementing the design attributes of the tax and reducing gaps between the effective taxation and what it is purported to be in the legislation. More broadly, a good tax administration, VAT administration in this case, is important to achieve the policy objectives of a government.

3. Using VAT as policy instrument is possible because of its power to influence consumers and business men to act in a desired manner. This is because VAT touches every angle of the economy directly or indirectly.

4. In order to control right amount of VAT collected, the tax authority should undertake unexpected checking of accounts of business, hiring competent auditors and lawyers.

5. Rules and regulations should be implemented effectively and some fast and hard rules should be acted. If this is the case, business peoples de-motivate to perform illegal activity.

6. Skilled manpower is an engine for effective and efficient implementation of tax.

\section{References}

1. Addis Zemen. (2016). Amharic News Papers, 193, Saturday, Megabit 13.

2. Alain Charlet and Jeffrey Owens (2016). An International Perspective on VAT: International Monetary Fund (IMF).

3. Best and Kahin (2017). Research in Education.: A vaicom Company.

4. Council of Ministers-Federal Democratic Republic of Ethiopia. (2015). Value Added Tax proclamation, Federal Negarit Gazeta, Addis Ababa, Ethiopia.

5. Council of ministers. (2018). Value added tax proclamation no. 79/2002, Negarit Gazetta, FDRE.

6. Dasalegn MosissaJalata march (2014). The role of VAT on Economic Growth of Ethiopia. Sci. Technol. Arts Res. J, 156-161.

7. Donald Kisilu Kombo and Delno Tromp (2017). Proposal and Thesis Writing. Kenyatta univesty: Pauline publication Africa.

8. Ethiopian Revenue and Customs Authority (ERCA) (2015). Satirical Bullet Vol-1. Addis Ababa, Ethiopia: A Publication of Macro- Data Processing and Analysis Team Planning and Performance Monitoring Directorate.

9. Federal Inland Revenue Authority (FIRA,2014). Components of Tax Administration. Tax, 1(3), Federal Inland Revenue Authority (FIRA, 2015), Addis Ababa.

10. Gebrie W. (2016) Tax Accounting in Ethiopian context, Alem printing press, Ethiopia.

11. H.L Bhatia, (2016). Public Finance, 24th edition.

12. Michael Keen and Ben L. (2015) The Value-Added Tax: Its Causes and Consequences, working paper no 183.

13. Minister of Finance and Economic Development (MoFED, 2017). Fiscal Policy Accounting and Finance Department Office.

14. Misrak Tesfay Abate (2014). Ethiopian tax accounting, principles and practice 2ndedition. Addis Ababa, Ethiopia: Woinshet Chane printing press.

15. Muhibat Abdul Azeez and Top Lawal (2016). Empirical Evaluation of Contribution.

16. Muluneh Beyene. (2017). Determinants of tax payers voluntary compliance, Addis Ababa, Ethiopia.

17. Richard M. Bird and Joseph L. Rotman (2016). Value Added Taxes in Developing and Transitional countries: Lessons and Questions. A Paper prepared for the first GlobalInternational Tax Dialogue Conference.

18. Yohannes Mesfin and Sisay Bogale (2015). Ethiopian Tax Law, Teaching Material

19. VAT to Total Revenue Generation and GDP in Nigeria. Faculty of Economics and muamalat, university sainsislam Malaysia, 1296-1309.

20. Yohannes Mesfin and Sisay Bogale (2015). Ethiopian Tax Law, Teaching Material.

21. VAT exemption on imported food on total government revenue. (2017). Addis Ababa University (AAU) Accounting and finance thesis. 